УДК 004.043:004.051:004.91

DOI https://doi.org/10.32838/2663-5941/2021.1-1/10

\title{
Зіноватна С.Л.
}

Одеський національний політехнічний університет

\section{Комлева О.O.}

Одеський національний політехнічний університет

\section{Улізко Г.В.}

Одеський національний політехнічний університет

\section{Писаренко К.О.}

Одеський національний політехнічний університет

\section{УПРАВЛІННЯ ВИМОГАМИ ДО ТЕКСТОВОГО РЕДАКТОРА З МОЖЛИВІСТЮ ДОДАВАННЯ АУДІОНОТАТОК}

Управління вимогами до програмного забезпечення передбачає формалізацію функиіональних та нефункиіональних вимог до розроблюваного програмного продукту, їх документування, визначення зацікавлених у процесі розроблення осіб та багато інших питань. Загалом, є багато факторів, які впливають на прочес управління вимогами під час розроблення програмного забезпечення: географічна розподіленість команд розробників, складність розроблення, невизначеність у вимогах, неякісні вхідні дані та ін. Цю статтю присвячено формалізаџї функціональних та нефункиіональних вимог до текстового редактора з можливістю спільної онлайн-роботи сукупності користувачів та використання аудіонотаток. У межах аналізу актуальності обраної теми вивчено наявні програмні аналоги: Google Docs, OneNote ma Simplenote. Як показав аналіз, незважсаючи на наявність якісних аналогів, розроблення текстового редактора з можливістю додавання аудіонотаток є актуальним завданням, тому потрібно зосередитись на структурі відповідних вимог. Основними функиіями онлайн-редактора є такі: робота з текстовим файлом із можливістю створення та використання аудіо- та текстових нотаток до певних фрагментів тексту, пошук коментарів за ключовими словами, редагування тексту документа, підсумкове оцінювання якості контенту документа та ін. Основними нефункиіональними характеристиками розроблюваного продукту є такі: надійність, щчо забезпечується певними характеристиками відмовостійкості та відновлюваності, юзабіліті, шо включає зрозумілість користування продуктом та привабливість інтерфейсу, та переносимість, тому що продукт є вебзастосуванням та повинен бути адаптованим до різних пристроїв та платформ. У роботі виконано трирівневу декомпозицію робіт для проведення планування розроблення відповідного продукту. Основними елементами декомпозиції є організаційні роботи, щчо містять планування розроблення та організацію супроводження продукту, розроблення власного програмного продукту та маркетингові дії щодо просування продукту на ринку, зокрема використання механізмів реклами, аналіз ринку та управління продуктом.

Ключові слова: онлайн-редактор, аудіонотатки, управління вимогами, функиіональні вимоги, нефункціональні вимоги, структура декомпозиції робіт, проектний менеджмент.

Постановка проблеми. Управління вимогами до програмного забезпечення - складний процес, який потребує вирішення сукупності проблем. Насамперед це ідентифікація та документування вимог, потім - узгодження їх пріоритетів. Аналіз здійсненності як етап процесу розроблення дозволяє оцінити вартість вимог та їх відповідність до наявних умов розроблення. За заздалегідь визначених умов розроблення програмного продукту дуже важливим $\epsilon$ правильне оцінювання наявних ресурсів. Тому необхідно здійснювати планування процесу розроблення з обов'язковою декомпозицією робіт. У разі виникнення ризиків щодо успішності розроблення необхідно вживати заходів щодо їх урегулювання.

Аналіз останніх досліджень і публікацій. Відомо, що є багато факторів, що впливають на процес управління вимогами в завданнях розроблення програмного забезпечення. Питанню особливостей розроблення програмного забезпечення iз залученням механізмів аутсорсингу присвячено роботу $[1$, с. 623$]$. Автори розглянули виявлені 
проблеми інженерії вимог щодо їх відповідності різним типам організації (клієнт і постачальник) та розмірам (малим, середнім та великим) із метою забезпечення чіткого розуміння процесу інженерії вимог та факторів його успіху в контексті різних офшорних організацій з аутсорсингу програмного забезпечення. У роботі [2, с. 1553] показано, що інженерія вимог та управління змінами вимог вважаються дуже складними видами діяльності через вимогливість до численних комунікацій, при цьому більшість факторів успіху пов'язані зі сферою знань про людські ресурси. Питанню необхідності ретельного вибору інформаційно-технічних ресурсів під час розроблення програмного забезпечення присвячено роботу [3, с. 1]. Авторами показано, що під час переходу на використання хмарних сервісів для клієнтів більш складною стає оцінка загроз безпеки їх програмних застосувань. Традиційні методи оцінки ризику не можуть вирішити ці проблеми, оскільки вони не розглядають безпеку хмарних серверів як критичні системні ресурси, які необхідно захищати для запобігання успішної атаки. Авторами запропоновано проведення оцінки ризиків на етапі проектування програми шляхом відпрацювання випадків некоректного використання доступу до хмари.

Про необхідність ретельно оцінювати вірогідність даних, що можуть впливати на процес управління вимогами, вказано у роботах $[4$, с. 91 ; 5 , с. 109]. Авторами наведено множину кількісних і якісних критеріїв для формалізації джерел інформації. Використання цих критеріїв дозволяє проводити моделювання цільових процесів оброблення даних та отримувати програмний продукт iз певними характеристиками. Серед робіт, присвячених удосконаленню процесу розроблення складного програмного забезпечення та підвищення якості вхідних даних, слід виділити праці $[6$, c. $262 ; 7$, c. $430 ; 8$, c. 376$]$.

Цю роботу присвячено формалізації функціональних та нефункціональних вимог до текстового редактора 3 можливістю додавання аудіонотаток та плануванню його розроблення згідно 3 декомпозицією робіт. У межах аналізу актуальності обраної теми вивчено наявні програмні аналоги: Google Docs, OneNote та Simplenote.

Редактор Google Docs дозволяє коментувати текст на полях. Це $є$ корисним, коли над текстом працюють кілька людей. У $[9$, с. $1 ; 10$, с. 85] показано, що групова робота Google Docs концептуалізується як гібридний простір, який впливає на спільну та кооперативну діяльність. Акцент у роботі зроблено на тому факті, що, оскільки
Google Docs часто асоціюють зі співпрацею, його використання допомагає окремим членам групи встановити мультимодальне керівництво, щоб домінувати в гібридному просторі. У [11, с. 787 ; 12, с. 227] показано ефективність використання онлайн-редагування за допомогою Google Docs для розвитку навичок академічного письма у курсі IELTS. Однак можливість додавати аудіонотатки тут відсутня.

OneNote - зручне і просте у використанні застосування з пакета MS Office, позиціонується як заміна звичайного блокнота. Працює на операційних системах Windows, Mac, iOS i Android. Робочий простір - порожній лист, у будь-якому місці якого можна вводити текст, робити рукописні замітки і рисунки, а також записувати голосові коментарі [13, с. 467]. Недолік - застосування платне. Результати ставлять під сумнів припущення, що студенти можуть придбати найбільш відповідні технологічні інструменти для взаємодії 3 OneNote через досить високу вартість застосування [14, с. 9838$]$.

Simplenote - безкоштовний і досить простий текстовий редактор, назва якого говорить сама за себе. Швидко синхронізує замітки на всіх пристроях, підтримує спільну роботу над ними. Дозволяє створювати і зберігати необмежену кількість заміток, але тільки текстових, без вставки зображень і мультимедійних файлів [15, с. 83].

Таким чином, як показав аналіз, незважаючи на наявність якісних аналогів, розроблення текстового редактора 3 можливістю додавання аудіонотаток $€$ актуальним завданням, тому потрібно зосередитись на структурі відповідних вимог.

Постановка завдання. Метою роботи $\epsilon$ формалізація вимог до онлайн-редактора 3 можливістю спільного редагування тексту та додавання аудіонотаток.

Виклад основного матеріалу дослідження. Програмна система розроблюється як онлайнредактор 3 інтуїтивно зрозумілим інтерфейсом, можливістю спільного редагування та коментування текстових документів. До фрагментів документів можна додавати текстові нотатки або ж аудіонотатки, використання яких дозволяє значно заощадити час. На рисунку 1 показано схему роботи програмного продукту у вигляді варіантів використання.

Типовими прикладами використання редактора є такі:

- спільна робота над текстом копірайтера та редактора (копірайтер створює публікацію, редактор вносить правки та залишає коментарі, за необ- 


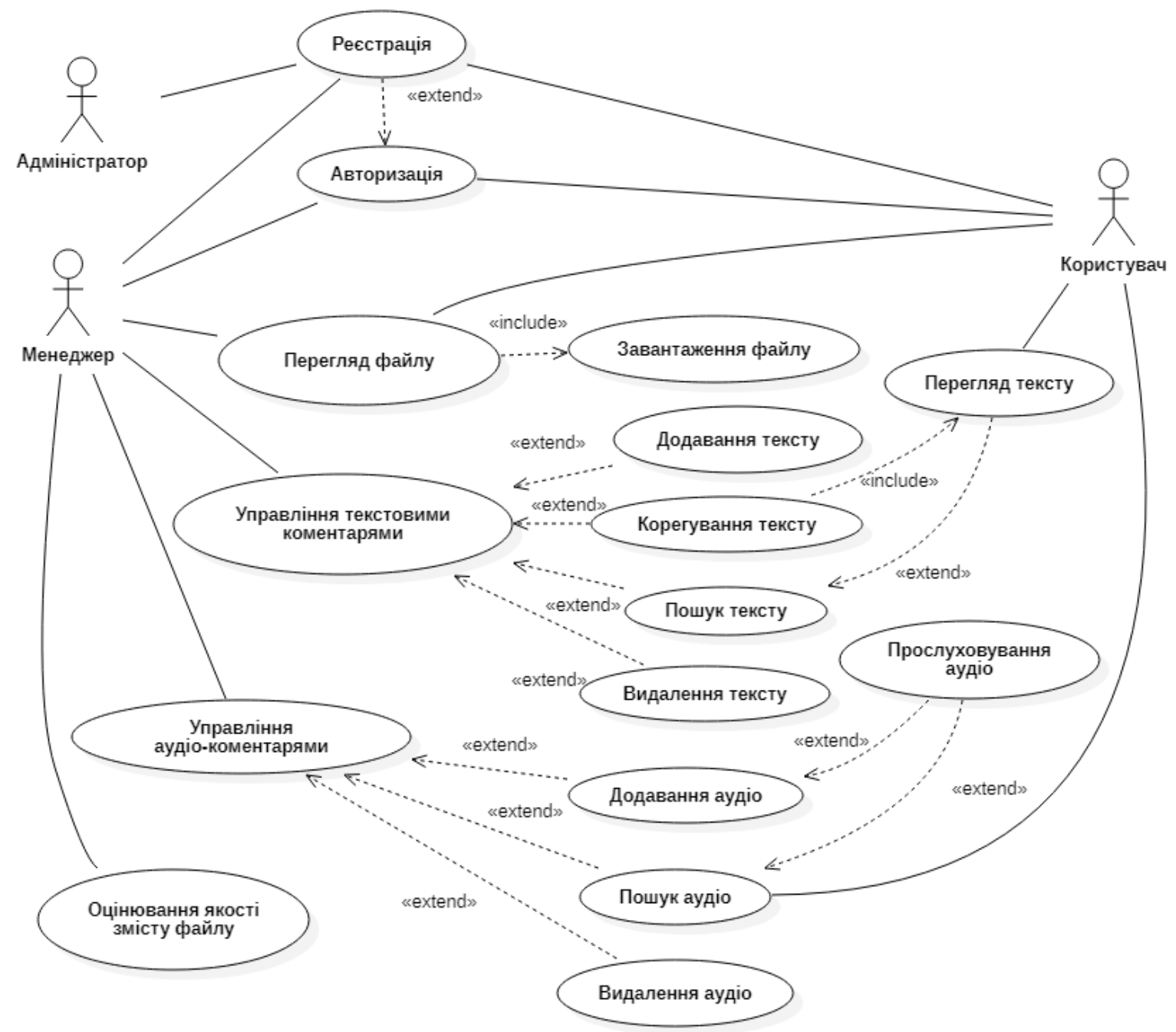

Рис. 1. Схема варіантів використання продукту

хідності до співпраці додається експерт із предметної сфери);

- перевірка вчителем/викладачем електронних письмових робіт учнів/студентів (учень робить письмове завдання, вчитель перевіряє його та коментує певні фрагменти. За необхідності процес стає ітераційним, критеріями завершення ітерацій можуть стати як досягнення певної якості роботи, так і вичерпання допустимого часу);

- допомога у вивченні іноземної мови (носій мови прикріплює приклади правильної вимови до певних слів або текстових фрагментів, користувач прослуховує їх та намагається повторити якомога ближче до оригіналу, за необхідності записує свою вимову).

Як можна побачити, в усіх випадках є головний актор (Менеджер), наділений більш широкими можливостями використання програми: редактор, учитель, носій мови і т.д. Саме він завершує спільне використання документа.
Адміністратор реєструє Менеджера та Користувача за їх електронними адресами. Для подальшої співпраці над документом Менеджер та Користувач повинні авторизуватись. Після завантаження в редактор текстового файла його можна переглядати та виконувати редагування (за необхідності). Усі зміни в документі автоматично зберігаються. Історія редагувань дозволяє відмінити зроблені зміни. Для додавання коментаря (нотатки) потрібно виділити текстовий фрагмент, до якого потрібно прив'язати коментар, натиснути праву кнопку миші та обрати з контекстного меню «Коментар аудіо» чи «Коментар текст». Після цього потрібно записати голосову нотатку чи у спеціальній формі створити текстовий коментар. Після закінчення формування коментаря фрагмент тексту, до якого він належить, позначається сірим кольором; на рівні першого рядка виділеного фрагмента ставиться позначка «аудіо» чи «текст». Треба зауважити, що до одного і того ж 
фрагмента тексту в документі не можна створити декілька коментарів.

За створеними коментарями можна здійснювати пошук. При цьому всі фрагменти тексту, до яких належать знайдені коментарі, та самі коментарі виділяються кольором. Для пошуку текстового коментаря треба ввести ключове слово чи словосполучення. Будуть знайдені всі коментарі, що їх містять. Для пошуку в аудіокоментарях потрібно створити аудіофрагмент із використанням мікрофона. Розпізнавання слів у фрагменті, а також текстових аналогів усіх аудіонотаток ведеться 3 використанням Java Speech API JARVIS. Це API, розроблений із використанням мовних механізмів, створених Google. Крім функцій пошуку, аудіо- та текстові нотатки можна видаляти. Для цього потрібно перейти до відповідного коментаря та здійснити видалення. Також можливим $є$ корегування текстових коментарів.

Після завершення роботи з документом Менеджер здійснює оцінювання якості змісту файла у зрозумілому для Користувача вигляді. Оцінювання проводиться у вільній формі: це може бути текстовий коментар до всього документа чи голосовий запис. Коментар може містити оцінку за певною шкалою чи повідомлення про прийняття роботи.

Зацікавленими особами (стейкхолдерами) під час розроблення проекту є Користувач, Менеджер, Адміністратор. Формалізація вимог стейкхолдерів передбачає визначення переліку цілей, методів їх досягнення та супутніх ризиків. Перелік основних цілей складають: результат необхідної якості, в термін, в межах бюджету; задоволення клієнта і команди; виконання зобов'язань за проектом із максимальною для виконавця користю; конкурентоспроможний продукт, який приносить певну користь.

Основними методами досягнення визначених цілей $\epsilon$ такі: виконання в повному обсязі завдання 3 дотриманням інтересів замовника і команди проекту; детальне планування й оперативне управління виконанням робіт із дотриманням вимог замовника й інтересів виконавців.

До ризиків розроблення проекту належать такі: низький рівень взаєморозуміння, взаємодії; неналежне виконання зобов'язань керівництва та стейкхолдерів; великий обсяг змін; низька кваліфікація робітників.

Відповідно до міжнародних стандартів, що визначають оціночні характеристики якості програмного забезпечення, виділено такі нефункціональні характеристики: надійність (reliability)-від- мовостійкість (fault tolerance) та відновлюваність (recoverability) продукту повинні забезпечувати його справну роботу; юзабіліті (usability) - використання продукту повинно бути зрозумілим (intelligibility) із мінімізацією зусиль на навчання для цього (learnability), інтерфейс повинен бути привабливим (attractiveness); переносимість (portability) - продукт є вебзастосуванням та повинен бути адаптованим (adaptability) до різних пристроїв та підтримувати кросплатформеність.

Під час планування розроблення проекту використано такі залежності між окремими завданнями: FS (Finish-Start) - виконання поточного завдання починається після завершення попереднього, SS (Start-Start) - виконання поточного завдання відбувається одночасно $з$ попереднім, FF (Finish-Finish) - виконання поточного i попереднього завдань завершується одночасно; SF (Start-Finish) - виконання поточного завдання завершується після початку виконання попереднього завдання.

Ієрархічну структуру робіт наведено на рисунку 2. На першому рівні декомпозиції виокремлено такі елементи, як «організаційні роботи», «розробка продукту» та «маркетинг продукту». Елемент «організаційні роботи» поділяється на «підготовку плану розробки» та «організацію супроводження продукту». Ці дії можуть виконувати окремі члени команди. «Підготовка плану розробки» поділяється на «технічне проектування» та «управління ресурсами проекту», які також можуть виконуватись окремими спеціалістами.

Наступним елементом першого рівня декомпозиції $\epsilon$ «розробка продукту». Цей елемент поділяється на «розробку програми», «тстування роботи програми» та «розробку дизайну». Для спрощення схеми WBS подальша декомпозиція «розробки програми» та «тестування роботи програми» не ведеться, тому що під час розроблення та тестування програмного коду кожна його частина може бути пов'язана 3 різними людьми, а їх кількість заздалегідь не є відомою. «Розробка дизайну» поділяється на «інтеграцію дизайну» та «програмування модулів дизайну». Ці елементи WBS так само виконують окремі члени команди.

Останній елемент першого рівня декомпозиції - «маркетинг продукту», тобто його просування. Він поділяється на «аналіз ринку» (тобто «вивчення попиту» та «аналіз конкурентів»), «управління продуктом» та «рекламу». «Управління продуктом» не $\epsilon$ фіксованим та може змі- 


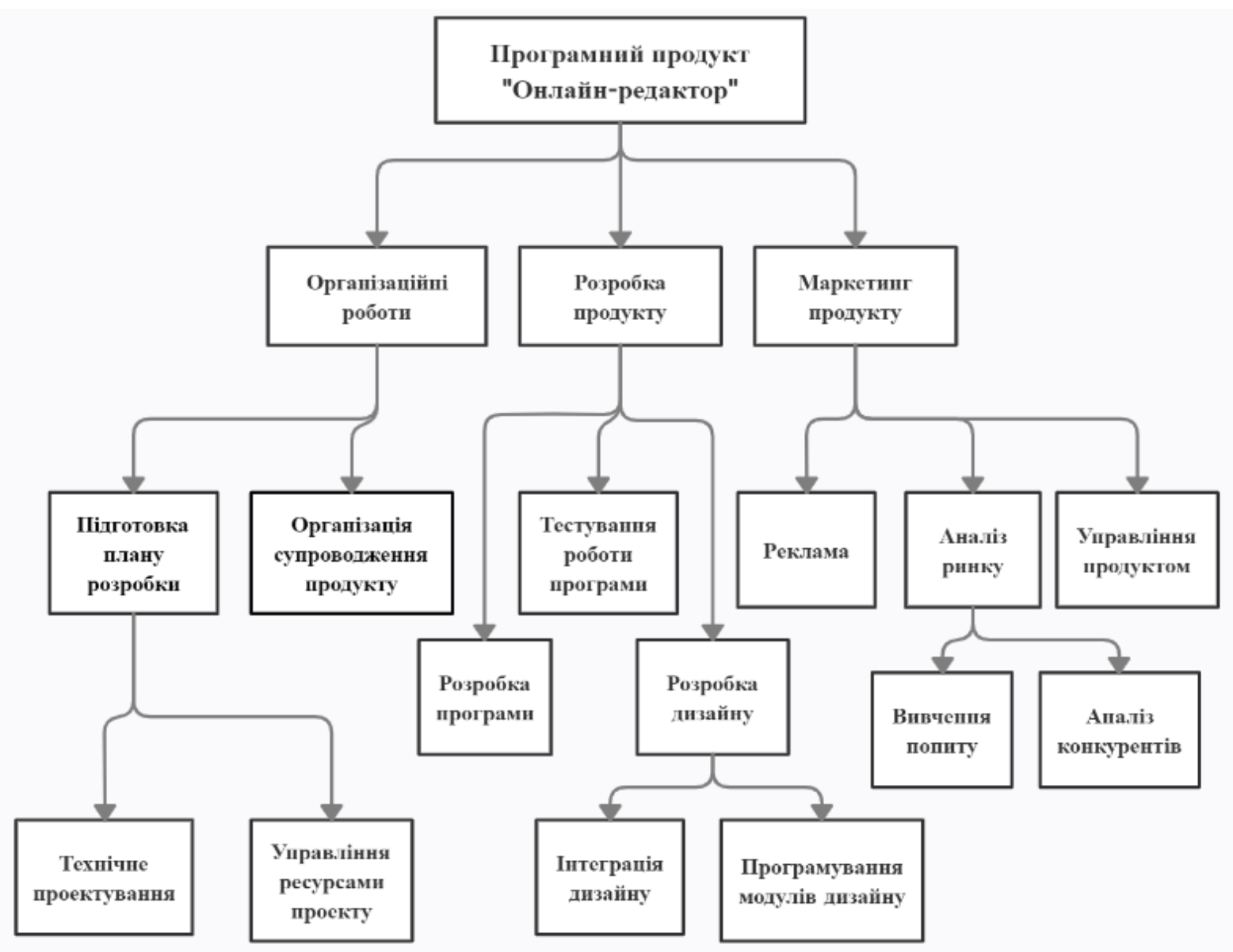

Рис. 2. Структурна декомпозиція робіт

нюватися, тому його декомпозиція на цьому етапі закінчена. Елемент «реклама» також може бути реалізований по-різному, спосіб реклами не є фіксованим, тому його декомпозиція на цьому також закінчена.

Висновки. У роботі проведено формалізацію функціональних та нефункціональних вимог до онлайн-редактора 3 можливістю додавання ауді- онотаток для спрощення спільної роботи над документами. Створено діаграму варіантів використання розроблюваного продукту. Наведено типові приклади використання онлайн-редактора. Розглянуто питання планування розроблення програмного продукту, виконано трирівневу структурну декомпозицію робіт, наведено відповідні описи робіт.

\section{Список літератури:}

1. Shafiq M., Zhang Q., Akbar M.A., Alsanad A., Mahmood S. Factors influencing the requirements engineering process in offshore software development outsourcing environments. IET Software. 2020. V. 14 (6). Pp. 623-637.

2. Niazi, M., Mahmood, S., Alshayeb, M., et al. Toward successful project management in global software development, International Journal of Project Management. 2016. Vol. 34. Pp. 1553-1567.

3. Sen A, Madria S. Application design phase risk assessment framework using cloud security domains. Journal of Information Security and Applications. 2020. Vol. 55. Article number 102617.

4. Крисилов В. А., Комлевая Н. О. Анализ и оценка компетентности источников информации в задачах интеллектуальной обработки данных. Международная научно-практическая конференция «Электротехнические и компьютерные системы: теория и практика» ELTECS-2019. Problemele energeticii regionale. Вып. 1-1 (40). 2019. С. 91-104.

5. Крісілов В.А., Комлева Н.О., Бурдейний С.І Програмна система аналізу якості джерел медичної статистичної інформації. Вчені записки ТНУ імені В.І. Вернадського. Серія: технічні науки. 2019. Том 30 (69) № 5. С. 109-115. 
6. Komleva N., Liubchenko V., Zinovatna S. Improvement of teaching quality in the view of a resource-based approach. CEUR Workshop Proceedings, 2020, 2740. Pp. 262-277.

7. Komleva N., Liubchenko V., Zinovatna S., Kobets V. Decision support system for quality management in learning process. CEUR Workshop Proceedings, 2020, 2711. Pp. 430-442.

8. Komleva N., Liubchenko V., Zinovatnaya S. Methodology of information monitoring and diagnostics of objects represented by quantitative estimates based on cluster analysis. Applied Aspects of Information Technology. 2020. V. 3. Pp. 376-392.

9. Olesen M. Cooperative Collaboration in the Hybrid Space of Google Docs Based Group Work. Education Sciences. 2020. Vol. 10. Is. 10. Article number 269.

10. Ishtaiwa F.F., Aburezeq I.M. The impact of Google Docs on student collaboration: A UAE case study. Learning Culture and Social Interaction. 2015. Vol., 7. Pp. 85-96.

11. Ebadi S., Rahimi M. Exploring the impact of online peer-editing using Google Docs on EFL learners' academic writing skills: a mixed methods study. Computer Assisted Language Learning. 2017. Vol. 30. Is. 8. Pp. 787-815.

12. Alharbi M.A. Exploring the potential of Google Docs in facilitating innovative teaching and learning practices in an EFL writing course. Innovation in Language Learning and Teaching. 2019. Vol. 14. Is. 3. Pp. 227-242.

13. Cavana, M. L. P. Using OneNote as an ePortfolio: Promoting Experiential Learning and Self-Regulation. Proceedings of the 18th European Conference on e-Learning. 2019. Pp. 467-475.

14. Bamforth S., Perkin G., Flint J. Understanding the student perspective of Microsoft OneNote as a learning resource in higher education. 12th International Conference of Education, Research and Innovation. 2019. Pp. 9838-9847.

15. Ovadia S. Writing in the cloud. Librarian's Guide to Academic Research in the Cloud. 2013. Pp. 83-102.

\section{Zinovatna S.L., Komleva O.O., Ulizko H.V., Pysarenko K.O. MANAGEMENT OF REQUIREMENTS FOR THE TEXT EDITOR WITH THE POSSIBILITY OF ADDING AUDIO NOTES}

Software requirements management involves the formalization of functional and non-functional requirements for the developed software product, their documentation, identification of stakeholders in the development process and many other issues. In general, there are many factors that affect the process of requirements management in software development: the geographical distribution of development teams, the complexity of development, uncertainty in the requirements, poor input, and others. This article is devoted to the formalization of functional and non-functional requirements for a text editor with the possibility of joint online work of a set of users and the use of audio notes. As part of the analysis of the relevance of the selected topic, the existing software analogues were studied: Google Docs, OneNote and Simplenote. As the analysis showed, despite the availability of high-quality analogues, the development of a text editor with the ability to add audio notes is an actual task, this means the need to focus on the structure of the relevant requirements. The main functions of the online editor are: working with a text file with the ability to create and use audio and text notes to specific fragments of text, search for comments by keywords, edit the text of the document, final evaluation of the quality of document content, etc. The main non-functional characteristics of the developed product are: reliability provided by certain characteristics of fault tolerance and recoverability; usability, including intelligibility of product use and attractiveness of the interface; portability, because the product is a web application and must be adapted to different devices and platforms. The work performed a three-level decomposition of tasks for planning the development of the product. The main elements of decomposition are organizational work, which includes planning the development and organization of product support, development of software product and marketing activities to promote the product on the market, including the use of advertising mechanisms, market analysis and product management.

Key words: online editor, audio notes, requirements management, functional requirements, non-functional requirements, work decomposition structure, project management. 